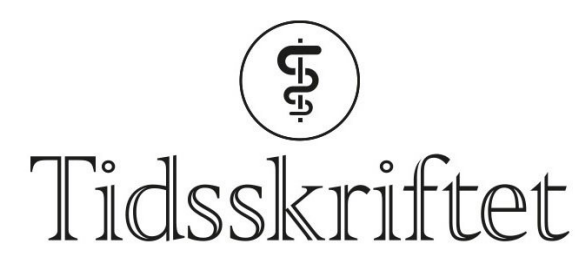

DEN NORSKE LEGEFORENING

\title{
Jan Erik Varhaug
}

MINNEORD

PER EYSTEIN LøNNING

ROLF KÅRESEN

ELLEN SCHLICHTING

JOHN-HELGE HEIMDAL

STENER KVINNSLAND

TURID AAS

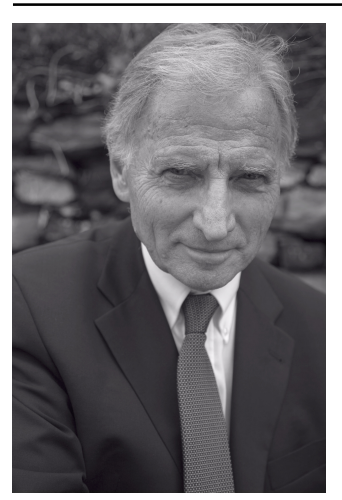

Det var med sorg vi mottok budskapet om professor Jan Erik Varhaugs bortgang 14 . desember 2017. Han var født i Kristiansand 1942, ble cand.med. 1967 og dr.med. 1984. I 1991 ble han professor ved Universitetet i Bergen, det første professoratet i bryst- og endokrinkirurgi i Norge. Han ble spesialist i generell kirurgi 1976 og i bryst- og endokrinkirurgi 2007. Han bygde opp seksjon for Bryst- og endokrinkirurgi ved Haukeland universitetssykehus, der han var i full jobb inntil 2012.

Hans forskning har vesentlig vært knyttet til brystkreft og endokrinkirurgi. Han var en tidlig pioner i samarbeidet mellom basalfag og klinikk lenge før begrepet «translasjonsforskning» ble kjent. Innen brystkreft har han vært sentral i tverrfaglige samarbeidsprosjekter. Fra 1991 bidro han til at pasienter med lokal, avansert brystkreft i studier fikk medikamentell behandling før operasjon, en behandling som da var kontroversiell, men i dag er etablert rutine. Han var en referanseperson i det norske endokrinkirurgiske miljøet og fikk henvist pasienter med vanskelige problemstillinger fra hele landet. 
Jan Erik Varhaug var med på å opprette Norsk Bryst Cancer Gruppe (NBCG) og var dens første leder 1988-91. Han var også sentral i oppbygging av nasjonale faggrupper og retningslinjer innen kreft i endokrine organer.

Han var en av initiativtakerne til egen spesialitet innen bryst- og endokrinkirurgi og han var den første lederen i spesialitetskomiteen. Han var æresmedlem i Norsk kirurgisk forening og i Norsk forening for bryst- og endokrinkirurgi. Han hadde bred internasjonal kontaktflate og flere studieopphold i så vel Europa som i USA.

I 2008 ble han utnevnt til Ridder 1. klasse av St. Olavs Orden.

Jan Erik Varhaug var på egne vegne en svært beskjeden mann til tross for den anerkjennelsen han fikk. Han var gjennomgående grundig i alt han gjorde og opptatt av at medisinske avgjørelser i pasientbehandlingen skulle være basert på evidens og forskningsresultater. Han var en av de mest helstøpte personligheter vi har møtt. Hans vennlighet og omsorg omfattet alle: pasienter, kolleger, venner og familie. Men samtidig var han kompromissløs, både overfor seg selv og andre, i kravet til faglig kvalitet.

Han etterlater seg et dypt savn. Jan Erik verdsatte familielivet høyt, noe han ofte ga uttrykk for. Våre tanker går til Inger Lene, barn, svigerbarn og barnebarn. Med ham er en hedersmann og nestor innen norsk medisin gått bort.

På vegne av kolleger og venner

Publisert: 19. februar 2018. Tidsskr Nor Legeforen. DOI: 10.4045/tidsskr.18.0039

(C) Tidsskrift for Den norske legeforening 2020. Lastet ned fra tidsskriftet.no 